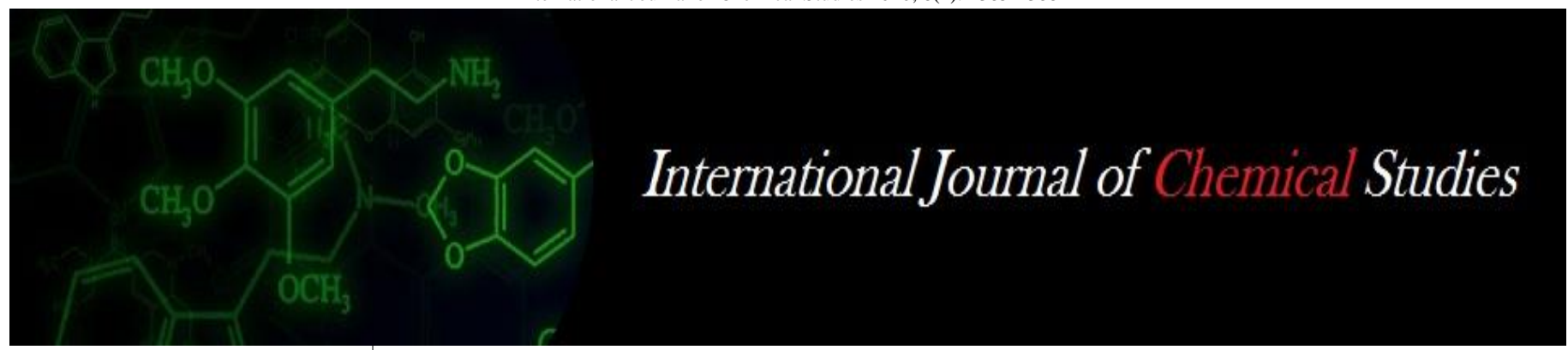

P-ISSN: 2349-8528

E-ISSN: 2321-4902

IJCS 2020; 8(1): 2385-2388

(C) 2020 IJCS

Received: 19-11-2019

Accepted: 21-12-2019

\section{MG Palakshappa}

All India Co-ordinated Research

Project on Sesame and Niger,

Main Agricultural Research

Station, University of

Agricultural Sciences,

Krishinagar, Dharwad,

Karnataka, India

Harshiya Banu

All India Co-ordinated Research Project on Sesame and Niger,

Main Agricultural Research

Station, University of

Agricultural Sciences,

Krishinagar, Dharwad,

Karnataka, India

\section{SG Parameshwarappa}

All India Co-ordinated Research

Project on Sesame and Niger,

Main Agricultural Research

Station, University of

Agricultural Sciences,

Krishinagar, Dharwad,

Karnataka, India

\section{Pooja Holeyannavar}

All India Co-ordinated Research

Project on Sesame and Niger,

Main Agricultural Research

Station, University of

Agricultural Sciences,

Krishinagar, Dharwad,

Karnataka, India

Corresponding Author:

MG Palakshappa

All India Co-ordinated Research

Project on Sesame and Niger,

Main Agricultural Research

Station, University of

Agricultural Sciences,

Krishinagar, Dharwad,

Karnataka, India

\section{Integrated management of Cercospora leaf spot and powdery mildew of sesame}

\author{
MG Palakshappa, Harshiya Banu, SG Parameshwarappa and Pooja \\ Holeyannavar
}

DOI: https://doi.org/10.22271/chemi.2020.v8.i1aj.8625

\begin{abstract}
Foliar diseases are the most destructive disease on Sesame. Among the foliar diseases Cercospora leaf spot, Alternaria blight, Powdery mildew and Bacterial blight are important diseases of sesame. Cercospora leaf spot caused by Cercospora sesamicola and powdery mildew caused by Oidium erysiphae are destructive diseases in India. Sesamum indicum has a large number of varieties and are susceptible to many pathogens. The occurrence and severity is location specific based on agro climatic situations. Hence, an attempt was made to identify the effective management practices for Cercospora leaf spot and powdery mildew in Sesame through integrated approach. Results revealed that, seed treatment with Trichoderma viride@10 g/kg and furrow application of enriched Trichoderma viride (Trichoderma viride $2.5 \mathrm{~kg}$ enriched in $100 \mathrm{~kg} \mathrm{FYM}$ ) @ $250 \mathrm{Kg} / \mathrm{ha}$ followed by spray of (Tebuconazole $50 \%$ + Trifloxistrobin 25\% WG) @ $0.5 \mathrm{~g} / \mathrm{l}$ recorded least per cent disease index for Cercospora leaf spot and powdery mildew 41.39 and 18.36 respectively, with the highest yield of $17.57 \mathrm{q} / \mathrm{ha}$ in treated as compared to untreated check 67.55 and 67.45 per cent disease index for Cercospora leaf spot and powdery mildew respectively, with grain yield of $7.59 \mathrm{q} / \mathrm{ha}$ indicating maximum yield loss. The maximum net returns and highest $\mathrm{B}$ : $\mathrm{C}$ ratio was also obtained in treatment (Tebuconazole 50\% + Trifloxistrobin 25\% WG) @ $0.5 \mathrm{~g} / \mathrm{l}$.
\end{abstract}

Keywords: Cercospora leaf spot, powdery mildew, integrated management, sesame

\section{Introduction}

Sesame (Sesamum indicum L.) is one of the oldest important oil seed crop and is under cultivation from ancient times. India is the fifth largest vegetable oil economy in the world, next only to USA, China, Brazil and Argentina and has an annual turnover of about Rs. 80,000 crore. India accounts for $12-15 \%$ of oilseeds area, $7-8 \%$ of oilseeds production, $6-7 \%$ of vegetable oils production, 9-12\% of vegetable oils import and 9-10\% of edible oils consumption (Jha et al., 2014) ${ }^{[4]}$. Among the oilseed crops. Sesame ranks first for its higher oil content with $6335 \mathrm{kcal} \mathrm{kg-1}$ of dietary energy in seeds (Kumar and Goel, 1994) ${ }^{[6]}$. India contributes the highest sesame acreage of 17.73 lakh hectares with the production of eight lakh tonnes and productivity of $445 \mathrm{~kg} /$ hectare. The low productivity is attributed to poor crop management and exposure of the crop to a number of biotic and abiotic stresses (Madhuri and Karuna Sagar, 2018) ${ }^{[7]}$. It is known as generally, til, popularly as "Queen of Oilseeds" due to its stabilized keeping quality contributed by high degree of resistance to oxidation (Bedigian and Harlan, 1986) ${ }^{[3]}$. Due to stability of its healthy oil, easiness of extraction and resistance to drought, sesame was popular in the ancient world. Sesame is considered as a nutritious oilseed crop being rich source of protein $(18-25 \%)$, carbohydrate $(13.5 \%)$, minerals and healthy polyunsaturated fatty acid (Bedigian, 1985). The area and production of sesame crop is gradually declining in the traditionally cultivated areas. Despite the potential for increasing the production and productivity of sesame, there are a number of challenges inhibiting sesame production and productivity. Among the many production constraints, the most important include lack of improved cultivars and poor seed supply system. In addition, there are severe biotic stresses, such as stem and root rot Macrophomina phaseolina (Tassi) Goid. Phytoplasma, Powdery mildew (Oidium erysiphoides), Alternaria leaf spot (Alternaria sesami) and Cercospora leaf spot (Cercospora sesamicola and, Cercospora sesami). Sesame diseases cause damage to seed, seedling, root, stem as well as foliage resulting in significant yield loss. (Madhuri and Karuna Sagar, 2018) ${ }^{[7]}$. 
The main reason for low productivity of this crop is due to fungal, bacterial and viral diseases. About 72 fungi, 7 bacteria, 1 phytoplasmal and 1 viral disease have been reported from India (Vyas et al, 1984) ${ }^{[9]}$. Out of these, about 32 diseases (14 major and 18 minor) occur in India. At present chemical fungicides are the first choice for the farmers to combat diseases because of their easy adaptability and immediate therapy. Due to health risk and pollution hazards by use of chemical fungicides in plant disease control, it is considered appropriate to minimize their usage. Since sesame seed and oil are in high demand for export due to their high unsaturated fat and methionine content, focus has been shifted to safer alternatives of chemical fungicides in recent years. Biological control had attained importance in modern agriculture to restrain the hazards of intensive use of chemicals for disease control. Since the efficacy of biocontrol agents in disease management has been inconsistent due to their inability to colonize and compete with other micro-organisms. Integrated diseases has emerged as the promising approach for management of foliar diseases of Sesame. Due to lack of resistant sources, the released varieties are highly susceptible to Cercospora leaf spot causing considerable yield losses. To combat the disease and maximize the production, there is an urgent need to manage the Cercospora leaf spot and powdery mildew of sesame through integrated approach.

\section{Materials and Methods}

The experiment was conducted during Kharif 2016-17 at AICRP on Sesame and Niger, Main Agricultural Research
Station, University of Agricultural Sciences, Dharwad using a susceptible local sesame cultivar DSS-9. The experiment was executed on 01.07 .2016 by using randomized complete block design of plot size $2.4 \mathrm{~m} \mathrm{X} 3.0 \mathrm{~m}$ with four replications. Spacing of $30 \mathrm{~cm} \mathrm{X} 10 \mathrm{~cm}$ was maintained. The fungicidal treatments were imposed immediately after appearance of the disease and subsequent sprays were given at an interval of 15 days presented in Table 1.

Table 1: List of fungicides used as foliar spray

\begin{tabular}{|c|c|c|}
\hline Treatments & Details of the Treatment & Dosage \\
\hline $\mathrm{T}_{1}$ & Spray of Myclobutanil & $1 \mathrm{~g} / \mathrm{l}$ \\
\hline $\mathrm{T}_{2}$ & Spray of Carbendazim 50\% WP & $1 \mathrm{~g} / 1$ \\
\hline $\mathrm{T}_{3}$ & Spray of (Cymoxanil 8\% + Mancozeb 64\% WP) & $2 \mathrm{~g} / 1$ \\
\hline $\mathrm{T}_{4}$ & $\begin{array}{c}\text { Spray of (Tebuconazole 50\% + Trifloxistrobin } \\
25 \% \text { WG) }\end{array}$ & $0.5 \mathrm{~g} / 1$ \\
\hline $\mathrm{T}_{5}$ & Spray of (Captan 70\% + Hexaconazole 5\% WP) & $2 \mathrm{~g} / 1$ \\
\hline $\mathrm{T}_{6}$ & Spray of Trichoderma viride & $0.4 \%$ \\
\hline $\mathrm{T}_{7}$ & $\begin{array}{c}\text { Spray of (Carbendazim 12\% + Mancozeb 63\% } \\
\text { WP) (Treated check) }\end{array}$ & $2 \mathrm{~g} / 1$ \\
\hline $\mathrm{T}_{8}$ & Untreated check & \\
\hline
\end{tabular}

Note: T1-T6 - Seed treatment with Trichoderma viride @ 10g/kg furrow application of enriched Trichoderma viride (Trichoderma viride $2.5 \mathrm{~kg}$ + FYM $100 \mathrm{~kg}$ ) @ $250 \mathrm{~kg} / \mathrm{ha}$

The observations were recorded at physiological maturity on five randomly selected plants using 0-5 scale (Kushwaha and Kaushal, 1970) for Cercospora leaf spot and the severity of powdery mildew was recorded (Anonymous, 2015) and presented in Table 2.

Table 2: Disease rating scale

\begin{tabular}{|c|c|}
\hline Disease grade & Description \\
\hline 0 & No infection (immune) \\
\hline 1 & $1-10 \%$ of leaf area infected (Highly Resistant) \\
\hline 2 & $11-25 \%$ of leaf area infected (Moderately Resistant) \\
\hline 3 & $26-50 \%$ of leaf area infected (Moderately Susceptible) \\
\hline 4 & $51-70 \%$ of leaf area infected (Susceptible) \\
\hline 5 & $>70 \%$ of leaf area infected (Highly Susceptible) \\
\hline
\end{tabular}

At physiological maturity (capsules turning to yellow colour) the plants were harvested, dried and per plot yield was recorded to compute the yield per hectare. The data on per cent disease index was worked out for Cercospora leaf spot and powdery mildew of sesame. The data were subjected to angular transformations and analyzed using standard statistical procedures.

\section{Results and Discussion}

The effective fungicides and bio-control agents revealed that the effects of all the treatments were found significantly superior over control in reducing the disease severity and increasing grain yield. Seed treatment with Trichoderma viride @ $10 \mathrm{~g} / \mathrm{kg}$ and furrow application of enriched Trichoderma viride (Trichoderma viride $2.5 \mathrm{~kg}+$ FYM 100 $\mathrm{kg}$ ) applied @ 250 Kg/ha followed by spray of combi product (Tebuconazole 50\% + Trifloxistrobin 25\% WG) @ $0.5 \mathrm{~g} / \mathrm{l}$ recorded minimum disease severity index for Cercospora leaf spot (41.39 PDI) and powdery mildew (18.36 PDI) with higher economic yield $(17.57 \mathrm{q} / \mathrm{ha}$ ) followed by (Cymoxanil $8 \%$ + Mancozeb 64\% WP) @ 2g/l for Cercospora leaf spot (45.12 PDI) and spray of Carbendazim 50\% WP @ 1g/l (21.47 PDI) and Myclobutanil @ 1g/1 (22.58 PDI) for powdery mildew compared to untreated check with per cent disease index of 67.55 and 67.45 for Cercospora leaf spot and powdery mildew respectively. The average grain yield/plot was highest $(1265 \mathrm{~g})$ as compared to average in yield/plot $(546 \mathrm{~g})$ in untreated check and test weight of $3.55 \mathrm{~g}$ recorded in (Tebuconazole 50\% + Trifloxystrobin 25\% WG)@ $0.5 \mathrm{~g} / 1$ and was significant over untreated check Table 3.

The present findings revealed that the application of combi product (Tebuconazole 50\% + Trifloxystrobin 25\% WG) @ $0.5 \mathrm{~g} / \mathrm{l}$ can be used for the effective management of Cercospora leaf spot and powdery mildew. Palakshappa et al., 2012 reported usage of (Carbendazim 25\% WP + Iprodion $25 \% \mathrm{WP}$ ) at 0.1 per cent for effective management of Cercospora leaf spot in Sesame. Madhuri and Karuna Sagar, $2018{ }^{[7]}$ reported that Carbendazim @ 0.1\% have showed better controlling potential against powdery mildew and recommended for use against powdery mildew in Sesame.

The economics of fungicides on severity of Cercospora leaf spot and powdery mildew with seed yield (Tebuconazole 50\% + Trifloxistrobin 25\% WG) @ $0.5 \mathrm{~g} / \mathrm{l}$ recorded highest seed yield $(17.57 \mathrm{q} / \mathrm{ha})$ and $\mathrm{B}$ : C ratio of 1: 4.15 followed by (Carbendazim 12\% + Mancozeb 63\% WP) @ 2 g/l with seed yield of $13.51 \mathrm{q} / \mathrm{ha}$ and $\mathrm{B}$ : C ratio of 1: 3.49 by considering the average market price prevailed for three months in the Agricultural Produce Market Committee (APMC). 
Highest income in treatment (Rs. 1, 20, 256), additional income (Rs. 68,194), net returns (Rs. 91,156) and B: C ratio 1:4.15 have encouraged the recommendation of combi product (Tebuconazole 50\% + Trifloxystrobin 25\% WG) @ $0.5 \mathrm{~g} / \mathrm{l}$ for efficient management of Cercospora leaf spot and powdery mildew of Sesame.

Table 3: Integrated management of Cercospora Leaf Spot and powdery mildew of Sesame

\begin{tabular}{|c|c|c|c|c|c|}
\hline $\begin{array}{l}\text { Sl. } \\
\text { No. }\end{array}$ & Treatment & \begin{tabular}{|c|} 
Cercospora Leaf Spot $(\mathrm{Per}$ \\
cent disease index $)$
\end{tabular} & $\begin{array}{c}\text { Powdery mildew } \\
\text { (Per cent disease index) }\end{array}$ & $\begin{array}{r}\text { Yield } \\
(\mathrm{q} / \mathrm{ha})\end{array}$ & \begin{tabular}{|c|} 
Test \\
weight $(g)$
\end{tabular} \\
\hline 1. & Spray of Myclobutanil @ 1g/l & \begin{tabular}{|c|}
58.88 \\
$(50.14)$ \\
\end{tabular} & $\begin{array}{c}22.58 \\
(27.89) \\
\end{array}$ & 12.07 & 3.11 \\
\hline 2. & Spray of Carbendazim 50\% WP @ 1g/1 & $\begin{array}{c}58.36 \\
(49.85)\end{array}$ & $\begin{array}{l}21.47 \\
(27.60)\end{array}$ & 11.42 & 3.35 \\
\hline 3. & Spray of (Cymoxanil 8\% + Mancozeb 64\% WP) @ 2g/1 & $\begin{array}{c}45.12 \\
(42.21)\end{array}$ & $\begin{array}{c}52.12 \\
(46.23)\end{array}$ & 12.27 & 3.49 \\
\hline 4. & $\begin{array}{c}\text { Spray of (Tebuconazole 50\% + Trifloxystrobin 25\% WG) @ } \\
0.5 \mathrm{~g} / 1\end{array}$ & $\begin{array}{c}41.39 \\
(40.02)\end{array}$ & $\begin{array}{l}18.36 \\
(25.13)\end{array}$ & 17.57 & 3.55 \\
\hline 5. & Spray of (Captan 70\% + Hexaconazole 5\% WP) @ 2g/l & $\begin{array}{c}47.73 \\
(43.70)\end{array}$ & $\begin{array}{c}30.94 \\
(33.47)\end{array}$ & 12.88 & 3.59 \\
\hline 6. & Spray of Trichoderma viride @ $0.4 \%$ & $\begin{array}{c}63.21 \\
(52.68) \\
\end{array}$ & $\begin{array}{c}51.24 \\
(45.64) \\
\end{array}$ & 11.43 & 3.33 \\
\hline 7. & $\begin{array}{l}\text { Spray of (Carbendazim 12\% + Mancozeb 63\% WP) @ 2g/1 } \\
\text { (Treated check) }\end{array}$ & $\begin{array}{c}49.84 \\
(44.92)\end{array}$ & $\begin{array}{c}38.63 \\
(38.17)\end{array}$ & 13.51 & 3.34 \\
\hline 8. & Untreated Check & $\begin{array}{c}67.55 \\
(55.35)\end{array}$ & $\begin{array}{c}67.45 \\
(55.18)\end{array}$ & 7.59 & 3.10 \\
\hline & S.Em \pm & 1.99 & 3.60 & 0.79 & 0.06 \\
\hline & $\mathrm{CD}$ at $5 \%$ & 5.78 & 10.46 & 2.31 & 0.18 \\
\hline & $\mathrm{CV}(\%)$ & 8.30 & 18.51 & 12.73 & 3.66 \\
\hline
\end{tabular}

Note: T1-T6 - Seed treatment with Trichoderma viride @ 10g/kg -furrow application of enriched Trichoderma viride (Trichoderma viride 2.5kg

+FYM $100 \mathrm{~kg}$ )@ 250 kg/ha is common

Figures in patenthesis are angular transformations

Table 4: Economics of fungicidal spray in the management of Cercospora leaf spot and powdery mildew of Sesame

\begin{tabular}{|c|c|c|c|c|c|c|}
\hline $\begin{array}{l}\text { Sl. } \\
\text { No. }\end{array}$ & Treatments & $\begin{array}{c}\text { Income in } \\
\text { treatment } \\
(₹)^{\prime \prime}\end{array}$ & $\begin{array}{c}\text { Additional } \\
\text { Income } \\
\text { ( })\end{array}$ & $\begin{array}{c}\text { Total cost of } \\
\text { production } \\
(₹)\end{array}$ & $\begin{array}{c}\text { Net returns } \\
(₹)\end{array}$ & $\begin{array}{l}\text { B:C } \\
\text { ratio }\end{array}$ \\
\hline 1. & Spray of Myclobutanil @ 1g/l & 87996.00 & 30134 & 27300 & 54696 & 3.00 \\
\hline 2. & Spray of Carbendazim 50\% WP @ 1g/l & 78033.00 & 26171 & 26230 & 51803 & 2.97 \\
\hline 3. & Spray of (Cymoxanil 8\% + Mancozeb 64\% WP) @ 2g/l & 83841.00 & 31979 & 27933 & 55908 & 3.00 \\
\hline 4. & Spray of (Tebuconazole 50\% + Trifloxystrobin 25\% WG) @ 0.5g/l & 120056.00 & 68194 & 28900 & 91156 & 4.15 \\
\hline 5. & Spray of (Captan 70\% + Hexaconazole 5\% WP) @ 2g/l & 88009.00 & 36147 & 27600 & 60409 & 3.18 \\
\hline 6. & Spray of Trichoderma viride @ 0.4\% & 78102.00 & 26240 & 27256 & 50852 & 2.86 \\
\hline 7. & $\begin{array}{c}\text { Spray of (Carbendazim 12\% + Mancozeb 63\% WP) @ 2g/l } \\
\text { (Treated check) }\end{array}$ & 92314.00 & 40452 & 26440 & 65874 & 3.49 \\
\hline 8. & Untreated Check & 51862.00 & - & - & - & - \\
\hline
\end{tabular}

Note: T1-T6 - Seed treatment with Trichoderma viride @ 10g/kg -furrow application of enriched Trichoderma viride (Trichoderma viride 2.5kg +FYM $100 \mathrm{~kg}$ )@250 kg/ha is common

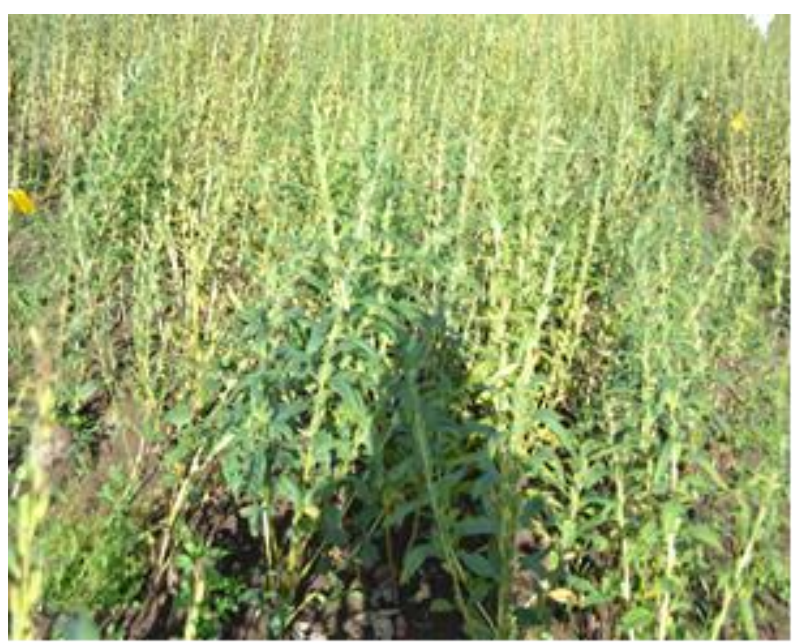

Seed treatment with Trichoderma viride @ 10g/kg-furrow application of enriched Trichoderma viride $(2.5 \mathrm{~kg}+$ $100 \mathrm{~kg}$ of FYM) @ $250 \mathrm{~kg} / \mathrm{ha}$ followed by spray of (Tebuconazole 50\% + Trifloxystrobin 25\% WG) @ 0.5g/l

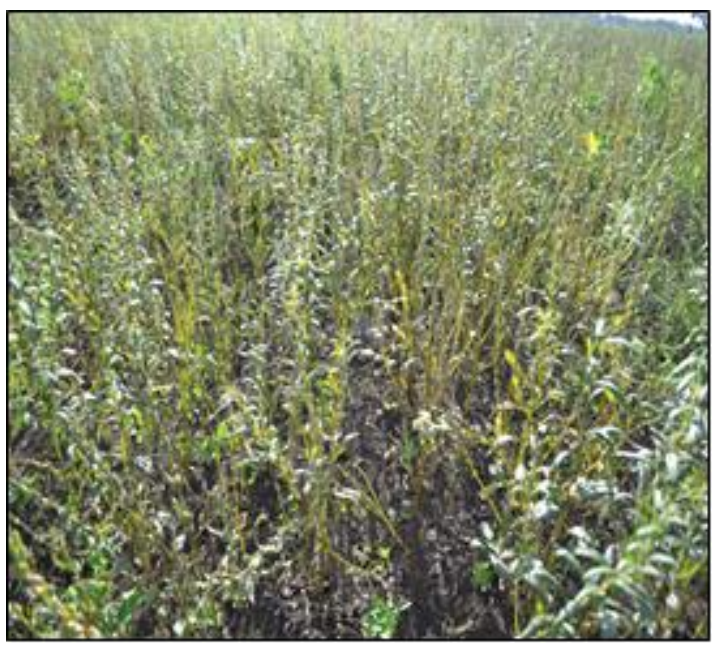

Untreated Check 

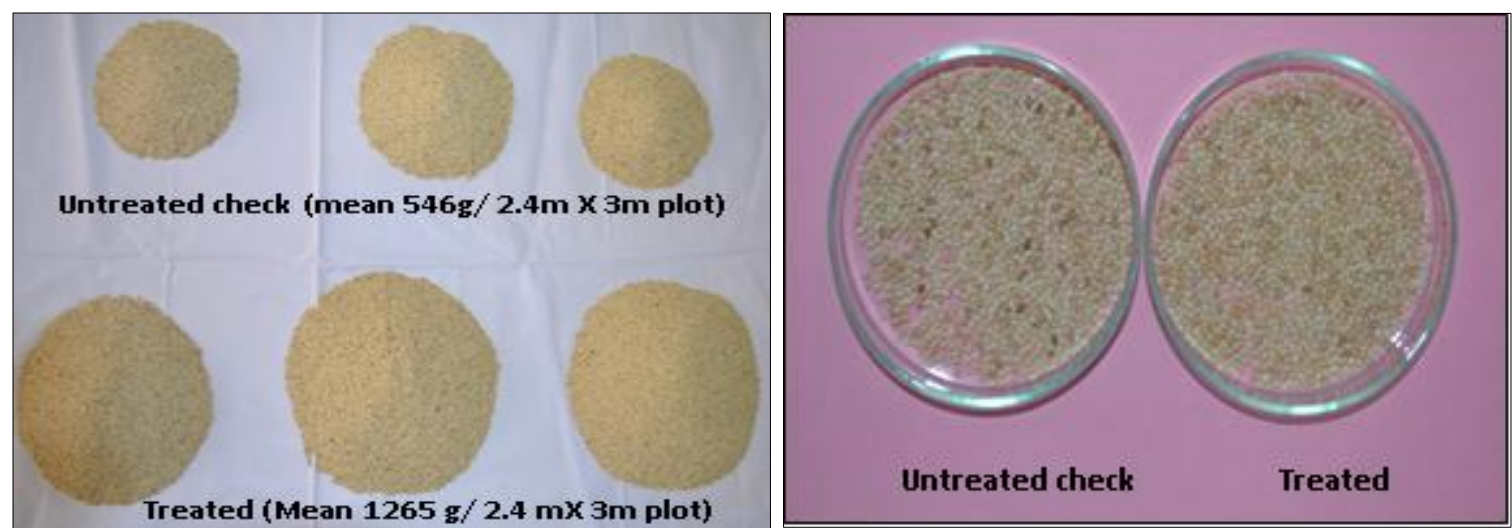

Fig 1: Integrated management of Cercospora leaf spot and powdery mildew of Sesame

\section{References}

1. Anonymous. Annual progress report, Sesame and Niger, Project Co-ordinating Unit (Sesame and Niger), J.N.K.V.V. Campus, Jabalpur. 2015.

2. Bedigian D. Is še-giš-i sesame or flax. Bull. Sumerian Agric. 1985; 2:159-178.

3. Bedigian D, Harlan JR. Evidence for cultivation of sesame in the ancient world. Economic Botany. 1986; 40:137-154

4. Jha GK, Pal S, Mathur VC, Bisaria G, Dubey SK. Edible oilseed supply and demands scenario in India: Implication of policy, Div Agric Economics, IARI, New Delhi, 2014.

5. Kushwaha US, Kausal PK. Reaction of Sesamum varieties to Cercospora leaf spot in Madhya Pradesh. Mysore J Agric. Sci. 1970; 4:228-230.

6. Kumar S, Goel PD. A great ancient oilseed Sesamum. Farmers and Parliament. 1994; 12:6-7.

7. Madhuri V, Karuna Sagar G. Management of Powdery Mildew Disease in Sesamum. Int. J Curr. Microbiol. App. Sci. 2018; 7(9): 3339-3344.

8. Palakshappa MG, Parameshwarappa SG, Lokesh MS, Deepakkumar Shinde G. Management of Cercospora leaf spot of sesame. International Journal of Plant Protection. 2012; 5(1):160-162.

9. Vyas SC, Prasad KVV, Khare MN. Diseases of Sesamum and Niger in India and their control. Department of Plant Pathology, JNKVV, Jabalpur, M. P. Bull, 1984, 16. 